\title{
Pendugaan Parameter Genetik Vigor untuk Viabilitas dan Vigor Benih Cabai (Capsicum annuum L.) Menggunakan Analisis Setengah Dialel
}

\author{
Genetic Parameters Estimation of Chilli (Capsicum annuum L.) Seeds Viability and \\ Vigor using Half Diallel Cross Analysis
}

\author{
Luluk Prihastuti Ekowahyuni ${ }^{1 *}$, M. Syukur ${ }^{2}$, Surjono H. Sutjahjo ${ }^{2}$, dan M. R. Suhartanto ${ }^{2}$
}

Diterima 09 Februari 2015/Disetujui 16 September 2015

\begin{abstract}
The purpose of this study was to estimate the narrow sense heritability $\left(h_{n s}^{2}\right)$, broad sense heritability $\left(h_{b s}^{2}\right)$, heterosis, and heterobioltiosis, coefficient of genetic variances, coefficient of phenotypic variances, additive and dominant variances. Pepper population used in this study consisted of IPB C2, IPB C9, IPB C10, IPB C15 and half diallel hybrid. To estimate the effect of reciprocal IPB C10 X IPB C2 hybrid was used. Accelerated aging method was used to test the vigor using methanol 20\% in five periods of time 0, 2, 4, 6 and 8 hours. Observations consisted of: (1) germination rate, (2) the length of radicle, (3) the length of hypocotile, (4) dry weight of normal seedlings, (5) speed of growth, (6) electrical conductivity and (7) moisture content. Genetic parameters were estimated using affinity analysis. Reciprocal effect indicated that there was no maternal effect. Parents with high combining ability was IPB C15 and that with high specific combining ability was IPB C2 $x$ IPB C5 and gave positive heterosis.
\end{abstract}

Key words: pepper, genetic coefficient, heterosis, seed vigor, specific combining ability

\begin{abstract}
ABSTRAK
Penelitian ini bertujuan menduga nilai parameter genetik untuk viabilitas dan vigor benih cabai menggunakan metode persilangan setengah dialel untuk mendapatkan informasi nilai heritabilitas, heterosis, koefisien keragaman genetik, varians aditif dan dominan, sehingga diharapkan dapat mendukung keberhasilan program pemuliaan yang mengkombinasikan karakter tanaman dengan viabilitas dan vigor benih yang baik. Empat genotipe tetua cabai yang digunakan adalah IPB C2, IPB C9, IPB C10, IPB C15, dan enam genotipe cabai hasil persilangan antar tetua adalah IPB C2 x IPB C9, IPB C2 x IPB C10, IPB C2 x IPB C15, IPB C9 x IPB C10, IPB C9 x IPB C15, IPB C10 x IPB C15. Rancangan percobaan yang digunakan adalah Rancangan Kelompok Lengkap Teracak (RKLT). Pengamatan untuk pengujian vigor dan viabilitas dilakukan pada genotipe tetua dan persilangan dengan tolok ukur yaitu (1) daya berkecambah (2) panjang akar, (3) panjang hipokotil, (4) bobot kering kecambah (5) kadar air benih, (6) kecepatan tumbuh (Kct), dan (7) daya hantar listrik (DHL). Pengujian vigor daya simpan benih cabai pada genotipe tetua dan persilangan menggunakan metode pengusangan cepat methanol $20 \%$. Setelah pengujian vigor daya simpan benih dilakukan analisis varian dan analisis regressi dan analisis statistik biometrik. Hasil analisis menunjukkan bahwa genotipe cabai IPB C15 mempunyai nilai daya gabung umum yang tinggi untuk vigor daya simpan benih sehingga dapat dijadikan sebagai tetua untuk perakitan varietas F1 hibrida vigor daya simpan benih tinggi. Kombinasi persilangan tetua IPB C2 x IPB C15 menghasilkan benih yang memiliki vigor daya simpan benih tinggi.
\end{abstract}

Kata kunci : cabai, daya gabung khusus, heterosis, koefisien genetik, vigor benih

\footnotetext{
${ }^{1}$ Fakultas Pertanian Universitas Nasional, Jl. Sawo Manila Pejaten No. 61 Pasar Minggu Jakarta Selatan 12520.

${ }^{2}$ Departemen Agronomi dan Hortikultura, Fakultas Pertanian, Institut Pertanian Bogor (Bogor Agricultural University), Indonesia Jl. Meranti Kampus Darmaga, Bogor 16680 Indonesia. Telp.\&Faks. 62-251-8629353.

*Email korespondensi: lulukprihastuti@yahoo.co.id.
} 


\section{PENDAHULUAN}

Informasi pendugaan parameter genetik sangat diperlukan untuk memperbaiki karakter suatu populasi. Parameter genetik dapat mendukung keberhasilan program pemuliaan tanaman, karena itu sangat penting dilakukan (Baihaki, 2009; Desita et al., 2015). Penelitian Syukur et al. 2010, berkaitan dengan pendugaan komponen ragam, heritabilitas dan korelasi pada populasi F5 cabai menunjukkan bahwa karakter yang dapat dijadikan karakter seleksi adalah karakter yang berkaitan dengan jumlah buah, bobot buah, dan karakter vegetatif tertentu. Pendugaan parameter genetik yang terkait dengan karakter vigor benih cabai belum banyak dan masih sangat sedikit informasinya.

Daya simpan benih dipengaruhi oleh faktor genetik dan kemungkinan dikendalikan oleh beberapa gen (Clerkx et al., 2004). Daya simpan benih dapat diduga dari vigor benih. Sadjad et al. (1999) menyatakan bahwa vigor benih yang tinggi mempunyai daya simpan yang tinggi. Daya simpan benih merupakan sifat kuantitatif yang dipengaruhi oleh faktor lingkungan selama pembentukan benih, panen dan penyimpanan. Penentuan daya simpan benih cabai masih memerlukan metode pengujian vigor daya simpan benih cabai.

Metode pengusangan cepat dengan methanol 20\% terpilih untuk pengujian vigor daya simpan benih yang digunakan untuk analisis pendugaan parameter genetik vigor benih cabai. Penelitian ini bertujuan menduga nilai parameter genetik untuk viabilitas dan vigor benih cabai menggunakan metode persilangan setengah dialel untuk mendapatkan informasi nilai heritabilitas, heterosis, koefisien keragaman genetik, varians aditif dan dominan, sehingga diharapkan dapat mendukung keberhasilan program pemuliaan yang mengkombinasikan karakter tanaman dengan viabilitas dan vigor benih yang baik.

\section{BAHAN DAN METODE}

Percobaan dilakukan di laboratorium Ilmu dan Teknologi Benih, Institut Pertanian Bogor. Percobaan dilakukan selama enam bulan sejak bulan Juni 2010 sampai dengan bulan Desember 2010.

\section{Metode Percobaan}

Bahan percobaan yang digunakan adalah IPB C2, IPB C9, IPB C10, IPB CI5 sebagai tetua dan $\mathrm{Fl}$ hasil persilangan yaitu IPB C2 x IPB C9, IPB C2 x IPB C10, IPB C2 $x$ IPB C15, IPB C9 x IPB C10, IPB C9 x IPB C15, IPB C10 x IPB C15 yang merupakan hasil persilangan (Tabel 1) digunakan untuk menduga efek resiprokal untuk persilangan antara tetua IPB C9 x IPB C10 dan IPB C10 x IPB C9.

Tabel 1. Persilangan pembentukan benih Fl untuk populasi studi

\begin{tabular}{ccccc}
\hline †/ภ & IPB & IPB & IPB & IPB \\
& $\mathrm{C} 2$ & $\mathrm{C} 9$ & $\mathrm{C} 10$ & $\mathrm{C} 15$ \\
\hline IPB C2 & $(\mathrm{X})$ & $\mathrm{X}$ & $\mathrm{X}$ & $\mathrm{X}$ \\
IPB C9 & - & $(\mathrm{X})$ & $\mathrm{X}$ & $\mathrm{X}$ \\
IPB C10 & - & - & $(\mathrm{X})$ & $\mathrm{X}$ \\
IPB C15 & - & - & - & $(\mathrm{X})$ \\
\hline
\end{tabular}

Keterangan : $\mathrm{X}=$ persilangan $:(\mathrm{X})=$ selfing

Rancangan percobaan yang digunakan adalah Rancangan Kelompok Lengkap Teracak (RKLT) dengan 3 ulangan. Kebutuhan benih per ulangan sebanyak 750 benih.

Bahan percobaan adalah benih galur tetua cabai koleksi plasma nutfah dan benih F1 hasil persilangan antar tetua yang merupakan hasil produksi benih tahun terbaru. Pengamatan untuk pengujian vigor dan viabilitas dilakukan pada genotipe tetua produksi terbaru dengan tolok ukur yaitu (a) panjang akar (PA), (b) tinggi batang (TB), (c) kadar air benih (KA), (d) daya berkecambah benih (DB), (e) kecepatan tumbuh (Kct), (f) daya hantar listrik (DHL), dan (g) indeks vigor (IV).

Pelaksanaan metode pengujian vigor benih cabai yaitu memproduksi benih cabai tetua dan persilangan menggunakan metode standar dan melakukan metode pengujian vigor benih pada benih tersebut menggunakan metode pengujian pengusangan cepat dengan methanol $20 \%$.

\section{Produksi Benih dan Pembentukan Populasi}

Pertama-tama yang dilakukan adalah memproduksi benih untuk pengujian pendugaan parameter genetik selama dua kali periode tanam. Prosedur penanaman untuk produksi benih menggunakan metode standar (Syukur et al., 2010). Pada tahap ini dilakukan persilangan antara tetua. Untuk memenuhi kebutuhan benih 
pengujian penanaman dilakukan 3 kali periode tanam. Pelaksanaan produksi benih cabai dilakukan dengan metode standar (Syukur et al., 2010) hanya pengecekan kondisi rumah percobaan dan pertanaman dilakukan secara ketat untuk menghindari serangan dari hama dan penyakit dan hasil benih yang tidak bermutu.

Setelah waktu pembungaan dimulai dilakukan penyilangan antar tetua. Emaskulasi dilakukan sebagai berikut: emaskulasi dan penyebaran dilakukan pagi hari pada pukul 06.00-09.00, menggunakan pinset yang telah disterilkan dengan alkohol 70\% pada saat tetua betina reseptif. Serbuk sari dan tetua jantan dikumpulkan dalam wadah tepung sari, selanjutnya serbuk sari ditempatkan ke stigma betina yang telah reseptif. Bunga yang telah diserbuki ditutup dengan selotip dan diberi label yang berisi informasi nama-nama kedua tetua dan tanggal persilangan. Selfing untuk perbanyakan tetua dilakukan dengan memberi sungkup pada bunga sehingga terjadi penyerbukan sendiri dengan sungkup individu.

Jika persilangan berhasil maka mahkota bunga akan lepas akibat pembesaran buah, sedangkan jika persilangan gagal maka bunga akan gugur dalam waktu 2-3 hari. Buah hasil persilangan dipanen saat buah cabai telah merah 100\% (masak fisiologis), setiap buah ditempatkan pada kantung terpisah dan diberi label.

Ekstraksi buah dilakukan menggunakan alat pinset dan pisau cutter, buah dibuka dan diambil benihnya satu persatu. Setelah diekstraksi benih diletakkan pada tempat yang kering dan dikering-anginkan selama 3-5 hari hingga kadar air (KA) benih kira-kira mencapai KA 8-11\%. Setelah itu benih dimasukkan dalam kotak penyimpanan yang kedap udara dan dimasukkan dalam ruang penyimpanan suhu $5-10{ }^{\circ} \mathrm{C}$.

Selanjutnya benih tetua dan hasil persilangan diuji dengan metode pengusangan cepat dengan methanol $20 \%$ periode $0,2,4,6$ dan 8 jam. Satu genotipe membutuhkan 2250 benih. Rancangan percobaan yang digunakan adalah Rancangan Kelompok Lengkap Teracak (RKLT). Pengamatan untuk pengujian vigor dan viabilitas tolok ukur yaitu (a) panjang akar (PA), (b) tinggi batang (TB), (c) kadar air benih (KA), (d) daya berkecambah benih (DB), (e) kecepatan tumbuh (Kct), (f) daya hantar listrik (DHL), dan (g) indeks vigor (IV).

\section{Analisis Data}

Analisis data yang digunakan adalah:

1. Analisis ragam menggunakan fasilitas software SAS 9.13 fortable.

2. Analisis daya gabung

Pendugaan daya gabung umum dan khusus berdasarkan metode II Griffing (Singh dan Chaudary, 1979).

3. Pengaruh resiprokal menggunakan uji t.

4. Pendugaan nilai heritabilitas arti luas $\left(h_{b s}^{2}\right)$ menurut Roy (2000):

$\sigma_{\mathrm{G}}^{2}=2 \sigma_{\mathrm{GCA}}^{2}+\sigma_{\mathrm{SCA}}^{2}$

$\sigma_{\mathrm{E}}^{2}=\sigma_{\mathrm{e}}^{2}$

$\sigma_{\mathrm{P}}^{2}=\sigma_{\mathrm{G}}^{2}+\sigma_{\mathrm{E}}^{2}$

$\mathrm{h}_{\mathrm{bs}}^{2}=\sigma_{\mathrm{G}}^{2} / \sigma_{\mathrm{P}}^{2}$

Keterangan:

$\mathrm{h}^{2}{ }_{\mathrm{bs}}=$ Heribilitas arti luas

$\sigma^{2}{ }_{\mathrm{G}}=$ Ragam genetik

$\sigma_{\mathrm{E}}^{2}=$ Ragam lingkungan

$\sigma_{\mathrm{e}}^{2}=$ Ragam ralat

$\sigma_{P}^{2}=$ Ragam fenotipe

5. Pendugaan nilai heritabilitas arti sempit $\left(h^{2}{ }_{\text {ns }}\right)$ menurut Roy (2000):

$\sigma_{\mathrm{A}}^{2}=2 \sigma_{\mathrm{GCA}}^{2}$

$\mathrm{h}_{\mathrm{ns}}^{2}=2 \sigma_{\mathrm{GCA}}^{2} /\left(2 \sigma_{\mathrm{GCA}}^{2}+\sigma_{\mathrm{SCA}}^{2}+\sigma_{\mathrm{E}}^{2}\right)$

Keterangan:

$\sigma_{\mathrm{A}}^{2}=$ Ragam aditif

$\sigma_{\text {ns }}^{2}=$ Heribilitas arti sempit

$\sigma^{2}{ }^{2}{ }_{C A}=$ Ragam daya gabung umum

$\sigma_{\text {SCA }}^{2}=$ Ragam daya gabung khusus

Klasifikasi nilai duga heritabilitas adalah sebagai berikut:

Tinggi $=\mathrm{h}^{2}{ }_{\text {bs }}>50 \%$

Sedang $=20 \%<\mathrm{h}^{2}{ }_{\mathrm{ns}}>50 \%$

Rendah $=\mathrm{h}_{\text {bs }}^{2} \leq 20 \%$

6. Pendugaan heterosis

Nilai heterosis diduga berdasarkan nilai tengah kedua tetua (mid parent) dan nilai tengah tetua terbaik (best parent) atau heterobeltiosis.

$\begin{array}{ll}\text { Heterosis } & =\frac{\mu \mathrm{F} 1-\mu \mathrm{FP} \times 100 \%}{\mu \mathrm{FP}} \\ \text { Heterobeltiosis } & =\frac{\mu \mathrm{F} 1-\mu \mathrm{BP} \times 100 \%}{\mu \mathrm{BP}}\end{array}$

Keterangan :

$\mu \mathrm{F} 1$ : nilai tengah turunan

$\mu \mathrm{MP}$ : nilai tengah kedua tetua $=1 / 2(\mathrm{P} 1+\mathrm{P} 2)$

$\mu \mathrm{BP}$ : nilai tengah tetua terbaik 


\section{Pendugaan daya gabung}

Untuk menduga nilai daya gabung umum (DGU) dan daya gabung khusus (DGK) dan pengaruh (DGK) dan pengaruh resiprokal genotipe-genotipe yang diuji, dilakukan analisis dialel menggunakan metode 2 Grifing (Sigh dan Chaudhary, 1979).

$Y i j=m+g i+g j+S i j+r i j$

Keterangan :

Yij : nilai tengah genotipe $\mathrm{i} x \mathrm{j}$

$\mathrm{m}$ : nilai tengah umum

gi : daya gabung umum (DGU) tetua ke-i

gj : daya gabung umum (DGU) tetua ke-j

Sij : pengaruh daya gabung khusus (DGK)

rij : pengaruh resipokal

1/bc $\sum \sum$ eijkl: nilai tengah pengaruh galat

Pengaruh daya gabung umum

(gi) $=1 / 2 n(Y i+Y j)-1 / n^{2} Y$.

Keterangan :

gi : nilai gabung umum

Yi : jumlah nilai tengah persilangan genotipe ke-i

$\mathrm{Yj}$ : jumlah nilai tengah selfing genotipe ke-j

Y.. : total nilai tengah genotipe

Pengaruh daya gabung khusus

$(\mathrm{Sij})=1 / 2(\mathrm{Yi}+\mathrm{Yij})-1 / 2 \mathrm{n}(\mathrm{Yi}+\mathrm{Yj}+\mathrm{Yj}+\mathrm{Yj})+1 / \mathrm{n}^{2} \mathrm{Y} \ldots$

Keterangan :

Sij) : nilai daya gabung khusus

Yij : nilai tengah genotipe $\mathrm{i} \times \mathrm{j}$

Yji : nilai tengah genotope $\mathrm{j} x \mathrm{i}$

Yi : jumlah nilai tengah persilangan genotipe ke-i

$Y . j \quad$ : jumlah nilai tengah selfing genotipe ke-j

$\mathrm{Yj} . \quad$ : jumlah nilai tengah persilangan genotipe ke-j

Y.. : total nilai tengah genotipe

Pengaruh resiprokal (rij) $=1 / 2(Y i j-Y j i)$

Keterangan :

rij : pengaruh resiprokal

Yij : nilai tengah genotipe $\mathrm{i} x \mathrm{j}$

Yji : nilai tengah genotipe $\mathrm{j} x \mathrm{i}$

ada tidaknya pengaruh resiprokal diindikasikan nilai $\mathrm{Yij}=\mathrm{Yji}$

\section{Pendugaan heterosis}

Nilai heterosis diduga berdasarkan nilai tengah kedua tetua (mid parent) dan nilai tengah tetua terbaik (best parent) atau heterobeltiosis.

Heterosis $=\frac{\mu \mathrm{F} 1-\mu \mathrm{MP} \times 100 \%}{\mu \mathrm{MP}}$
Heterobeltiosis $=\frac{\mu \mathrm{F} 1-\mu \mathrm{BP} \times 100 \%}{\mu \mathrm{BP}}$

Keterangan :

$\mu \mathrm{F} 1 \quad$ : nilai tengah turunan

$\mu \mathrm{MP}:$ nilai tengah kedua tetua $=1 / 2(\mathrm{P} 1+\mathrm{P} 2)$

$\mu \mathrm{BP} \quad$ : nilai tengah tetua terbaik

\section{HASIL DAN PEMBAHASAN}

Pendugaan parameter genetik dilakukan untuk mendapatkan nilai ragam aditif, ragam dominan, ragam genetik, ragam fenotipe, ragam lingkungan, daya gabung umum (DGU), daya gabung khusus (DGK), heritabilitas arti luas $\left(h^{2} b s\right)$, heritabilitas dalam arti sempit $\left(h^{2} n s\right)$, heterosis dan heterobioltiosis. Penggunaan metode silang dialel harus memenuhi enam asumsi, diantaranya adalah tidak ada perbedaan antara persilangan resiprokal (Singh dan Chaudary, 1979).

Uji $\mathrm{t}$ untuk melihat perbedaan antara persilangan resiprokal (Tabel 2). Berdasarkan uji t semua tolok ukur daya berkecambah, kecepatan tumbuh dan daya hantar listrik menunjukkan hasil tidak nyata. Hal ini menunjukkan tidak ada efek resiprokal pada laju penurunan vigor pada ketiga tolok ukur tersebut, dan ketiga tolok ukur tersebut dikendalikan oleh gen di dalam inti sel. Hal ini juga didukung oleh penelitian pada benih padi yang dilakukan oleh Akram et al. (2007) dan benih cowpea (Vigna unguiculata (L.) Walp.) yang dilakukan oleh Tchiagam et al. (2011).

Tolok ukur laju penurunan vigor pada panjang radikula dan panjang hipokotil, hasil uji t menunjukkan hasil yang nyata, Hal ini menunjukkan bahwa ada efek resiprokal, artinya pada kedua tolok ukur tersebut dikendalikan oleh gen di dalam sitoplasma dari maternal (Tabel 2).

Untuk melihat bagaimana metode pengujian vigor daya simpan benih pada persilangan dialel dilakukan analisis ragam pada data laju penurunan vigor daya simpan benih pada 5 tolok ukur (Tabel 3).

Hasil analisis ragam persilangan dialel menunjukkan bahwa dialel berpengaruh nyata pada laju penurunan (panjang radikula kecepatan tumbuh dan daya hantar listrik) dan tidak berbeda nyata pada laju penurunan (panjang hipokotil dan daya berkecambah) (Tabel 3).

Tetua berpengaruh nyata pada laju penurunan vigor pada (panjang radikula, 
panjang hipokotil dan daya hantar listrik) dan tidak nyata pada laju penurunan vigor pada (daya berkecambah dan kecepatan tumbuh). Persilangan berbeda nyata pada laju penurunan vigor (panjang radikula, kecepatan tumbuh dan daya hantar listrik) dan tidak nyata pada laju penurunan vigor pada (panjang hipokotil dan daya berkecambah).

Interaksi antara tetua dan persilangan tidak nyata pada hampir semua laju penurunan vigor pada (panjang radikula, panjang hipokotil, daya berkecambah dan kecepatan tumbuh) dan berbeda nyata hanya pada laju penurunan vigor daya hantar listrik. Ragam aditif lebih kecil dibandingkan ragam dominan. Hal ini menunjukkan bahwa untuk menghasilkan benih dengan vigor daya simpan benih cabai dapat dilakukan persilangan hibrida (Tabel 4) terutama pada laju penurunan vigor kecepatan tumbuh dan daya hantar listrik serta panjang radikula dan panjang hipokotil.

Hasil analisis ragam daya gabung menggunakan metode Griffing 2, menunjukkan bahwa pengaruh daya gabung umum (DGU) untuk vigor daya simpan benih cabai pada hampir semua tolok ukur nyata kecuali DB (Tabel 4). Hal ini mengindikasikan bahwa vigor daya simpan benih cabai dapat diperbaiki melalui perakitan varietas galur murni dan hibrida.

Nilai DGU merupakan dasar dalam pemilihan genotipe untuk dijadikan tetua persilangan (Tabel 5). Nilai DGU menunjukkan kemampuan genotipe untuk dapat bergabung dengan genotipe-genotipe lainnya (Singh dan Chaudary, 1979). Tetua yang memiliki nilai daya gabung umum tinggi dapat digunakan sebagai donor untuk sifat yang dipelajari (Mahmud et al., 1999). IPB CI 5 terpilih sebagai tetua yang mempunyai nilai DGU bernilai positif paling banyak yaitu 0.38 hingga 6.25. Urutan kedua pada laju penurunan vigor adalah tetua IPB C2 yaitu 0.7 sampai 3.77 (Tabel 5).

Tabel 2. Uji pengaruh maternal dan kehomogenan ragam populasi Fl dan F1R untuk data viabilitas dan vigor benih cabai

\begin{tabular}{|c|c|c|c|c|c|}
\hline Populasi & $\begin{array}{l}\text { Panjang } \\
\text { Radikula }\end{array}$ & $\begin{array}{c}\text { Panjang } \\
\text { Hipokotil }\end{array}$ & $\begin{array}{c}\text { Daya } \\
\text { Berkecambah }\end{array}$ & $\begin{array}{c}\text { Kecepatan } \\
\text { Tumbuh }\end{array}$ & $\begin{array}{c}\text { Daya Hantar } \\
\text { Listrik }\end{array}$ \\
\hline$\overline{F 1}$ & $21.38 \pm 2.14$ & $27.90 \pm 1.31$ & $27.04 \pm 4.44$ & $24.73 \pm 1.68$ & $29.39 \pm 0.64$ \\
\hline F1R & $36.23 \pm 2.94$ & $33.49 \pm 1.13$ & $17.38 \pm 11.21$ & $18.77 \pm 11.21$ & $20.41 \pm 1.98$ \\
\hline Prob $>|t|$ & $* *$ & $* *$ & tn & tn & tn \\
\hline Prof $>|F|$ & $* *$ & $* *$ & tn & tn & tn \\
\hline
\end{tabular}

Tabel 3. Hasil analisis ragam persilangan dialel laju penurunan vigor daya simpan benih cabai pada panjang radikula, panjang hipokotil, daya berkecambah, kecepatan tumbuh dan daya hantar listrik

\begin{tabular}{|c|c|c|c|c|c|c|}
\hline Sumber Keragaman & $\begin{array}{l}\text { Derajat } \\
\text { Bebas }\end{array}$ & $\begin{array}{l}\text { Panjang } \\
\text { Radikula }\end{array}$ & $\begin{array}{l}\text { Panjang } \\
\text { Hipokotil }\end{array}$ & $\begin{array}{c}\text { Daya } \\
\text { Berkecambah }\end{array}$ & $\begin{array}{l}\text { Kecepatan } \\
\text { Tumbuh }\end{array}$ & $\begin{array}{c}\text { Daya } \\
\text { Hantar } \\
\text { Listrik }\end{array}$ \\
\hline$\overline{\text { Ulangan }}$ & 2 & 28.72 & 11.94 & 10.00 & 382.62 & 3.71 \\
\hline Dialel & 9 & $242.21 * *$ & 60.78 tn & $17.47 \mathrm{tn}$ & $424.47 *$ & $312.95 *$ \\
\hline Tetua & 3 & $407.81 * *$ & $38.38 *$ & $8.69 \mathrm{tn}$ & 67.94 tn & $8.41 * *$ \\
\hline Persilangan & 5 & $187.42 * *$ & 85.89 tn & $26.23 \mathrm{tn}$ & $677.21 *$ & $471.12 * *$ \\
\hline Tetua x Persilangan & 1 & $19.29 \mathrm{tn}$ & 2.39 tn & $0.02 \mathrm{tn}$ & $230.42 \mathrm{tn}$ & $435.73 * *$ \\
\hline Galat & 18 & 35.92 & 28.57 & 12.10 & 133.23 & 1.98 \\
\hline
\end{tabular}


Daya gabung khusus (DGK) (Tabel 6) merupakan ekspresi genetik non-aditif, dominan dan epistasis (Roy, 2000). Mahmud et al. (1999) menyatakan nilai DGK yang tinggi menunjukkan adanya pengaruh aksi gen non aditif yang tinggi pada sifat tersebut. Menurut Basuki (1986) dalam memilih kombinasi persilangan yang baik selain nilai DGK perlu dipertimbangkan nilai tengah dari sifat yang akan diperbaiki. Sujiprihati (1996) menyatakan bahwa daya gabung khusus (DGK) positif menunjukkan bahwa tetua tersebut mempunyai kombinasi hibrida yang tinggi dengan salah satu tetua yang digunakan. Nilai DGK yang positif tertinggi adalah persilangan benih IPB C9 x IPB C10 (sebesar 28.54) disusul oleh persilangan IPB C2 x IPB C15 (11.20), IPB C2 x IPB C9 (10.30), IPB C9 x IPB C15 (5.91) dan IPB C10 x IPB C15 (5.06) (Tabel 6).
Heritabilitas dalam arti luas adalah proporsi besaran ragam genetik terhadap proporsi besaran ragam fenotipe suatu karakter tertentu (Tabel 6). Ragam genetik terdiri dari ragam aditif dan ragam non-aditif (dominan dan interaksi). Nilai duga heritabilitas yang tinggi menunjukkan bahwa pengaruh genetik lebih besar terhadap penampilan fenotipik dibandingkan pengaruh lingkungan (Sujiprihati et al., 2005).

Nilai duga heritabilitas dalam arti luas $\left(h^{2} b s\right)$ tertinggi hingga terendah berturut-turut sebagai berikut yaitu laju penurunan vigor pada daya hantar listrik yaitu 0.99 disusul oleh laju penurunan vigor pada (panjang hipokotil, panjang radikula, kecepatan tumbuh dan daya berkecambah) yaitu 0.91 sampai 0.57 menunjukkan tolok ukur tersebut dikendalikan oleh faktor genetik.

Tabel 4. Nilai analisis ragam daya gabung persilangan half diallel

\begin{tabular}{lrlccccc}
\hline $\begin{array}{c}\text { Sumber } \\
\text { Keragaman }\end{array}$ & \multirow{2}{*}{$\mathrm{db}$} & $\begin{array}{c}\text { Panjang } \\
\text { Radikula }\end{array}$ & $\begin{array}{c}\text { Panjang } \\
\text { Hipokotil }\end{array}$ & $\begin{array}{c}\text { Daya } \\
\text { Berkecambah }\end{array}$ & $\begin{array}{c}\text { Kecepatan } \\
\text { Tumbuh }\end{array}$ & Kadar air & $\begin{array}{c}\text { Daya Hantar } \\
\text { Listrik }\end{array}$ \\
\hline DGU & 3 & $149.13^{* *}$ & $1491286^{* *}$ & 79.89 tn & 222.44 tn & $2650518^{* *}$ & $638974^{* *}$ \\
DGK & 6 & $46.54^{*}$ & $465389^{*}$ & 47.41 to & $2011175^{* *}$ & $776844^{* *}$ & $1245286^{* *}$ \\
Galat & 18 & 11.97 & 119.73 & 40.33 & 444097.00 & 129.91 & 0.66 \\
Vadd & & 34.20 & 17.10 & 0.54 & -29.81 & 31.23 & -10.11 \\
Vdqm & & 34.57 & 34.57 & 0.71 & 156.71 & 123.87 & 123.87 \\
KK(\%) & & $23.96 \%$ & $23.96 \%$ & $10.90 \%$ & $33.21 \%$ & $4.98 \%$ & $4.98 \%$ \\
\hline
\end{tabular}

Keterangan: DGU= daya gabung umum; DGK= daya gabung khufcus; Vadd= varian/ragam aditif; Vdom= varian/ragam dominan; KK= Koefisen keragaman; $* *=$ berbeda sangat nyata; $*=$ berbeda nyata; $\mathrm{tn}=$ tidak nyata.

Tabel 5. Nilai daya gabung umum (DGU) vigor benih cabai

\begin{tabular}{lcccccc}
\hline Genotipe & $\begin{array}{c}\text { Panjang } \\
\text { Radikula }\end{array}$ & $\begin{array}{c}\text { Panjang } \\
\text { Hipokotil }\end{array}$ & $\begin{array}{c}\text { DGU Daya } \\
\text { Berkecambah }\end{array}$ & $\begin{array}{c}\text { Kecepatan } \\
\text { Tumbuh }\end{array}$ & Kadar Air & $\begin{array}{c}\text { Daya Hantar } \\
\text { Listrik }\end{array}$ \\
\hline IPB C2 & 3.77 & 1.19 & 1.33 & -2.74 & -3.68 & 0.70 \\
IPB C9 & -6.86 & -2.77 & -1.31 & 0.59 & -7.47 & 0.59 \\
IPB C10 & -0.52 & 0.09 & -0.51 & 1.77 & 4.90 & -1.07 \\
IPB C15 & 3.61 & 1.49 & 1.49 & 0.38 & 6.25 & -0.22 \\
\hline
\end{tabular}

Tabel 6. Nilai Daya Gabung Khusus (DGK) vigor benih cabai

\begin{tabular}{lcccccc}
\hline \multicolumn{1}{c}{ Genotipe } & $\begin{array}{c}\text { Panjang } \\
\text { Radikula }\end{array}$ & $\begin{array}{c}\text { Panjang } \\
\text { Hipokotil }\end{array}$ & $\begin{array}{c}\text { DGK Daya } \\
\text { Berkecambah }\end{array}$ & $\begin{array}{c}\text { Kecepatan } \\
\text { Tumbuh }\end{array}$ & $\begin{array}{c}\text { Kadar } \\
\text { Air }\end{array}$ & $\begin{array}{c}\text { Daya } \\
\text { Hantar Listrik }\end{array}$ \\
\hline IPB C2 x IPB C9 & 9.58 & 3.56 & 10.30 & -10.25 & -0.80 & -3.66 \\
IPB C2 x IPB C10 & -5.23 & -4.58 & 0.30 & -3.14 & -6.23 & -1.28 \\
IPB C2 x IPB C15 & 1.62 & -0.05 & 1.72 & 4.17 & 11.20 & 1.50 \\
IPB C9 x IPB C10 & -6.02 & -0.11 & -3.08 & 28.54 & -2.06 & 1.92 \\
IPB C9 x IPB CI5 & 5.91 & 0.74 & 0.02 & -5.97 & -2.06 & -0.75 \\
IPB C10 x IPB C15 & -1.93 & 5.06 & 2.45 & 0.23 & 3.74 & -3.03 \\
\hline
\end{tabular}


Tabel 7. Nilai heterosis semua tolok ukur viabilitas dan vigor benih cabai

\begin{tabular}{lcccc}
\hline \multicolumn{1}{c}{ Persilangan } & Heterosis & $\begin{array}{c}\text { Heterobeltiosis } \\
\text { Panjang Radikula }\end{array}$ & Heterosis & $\begin{array}{c}\text { Heterobeltiosis Panjang } \\
\text { Hipokotil }\end{array}$ \\
\hline IPB C2 x IPB C9 & -32.16 & -48.31 & 74.48 & 59.68 \\
IPB C2 x IPB C10 & -21.70 & -21.79 & 129.85 & 126.07 \\
IPB C2 x IPB C15 & 4.11 & -0.97 & 15.27 & 15.06 \\
IPB C9 x IPB C10 & -58.69 & -68.28 & 87.82 & 14.07 \\
IPB C9 x IPB C15 & -36.55 & -52.98 & 361.21 & 181.97 \\
IPB C10 x IPB C15 & 18.60 & 12.68 & 161.76 & 157.01 \\
\hline \multicolumn{7}{c}{ Daya Berkecambah } & Kecepatan Tumbuh \\
\hline IPB C2 x IPB C9 & -0.81 & -6.12 & -24.15 & -34.06 \\
IPB C2 x IPB C10 & -5.92 & -9.15 & -6.96 & -9.59 \\
IPB C2 x IPB C15 & 8.89 & 3.27 & 63.63 & 53.43 \\
IPB C9 x IPB C10 & -13.77 & -15.55 & 72.07 & 53.42 \\
IPB C9 x IPB C15 & 1.23 & 1.03 & -15.64 & -22.68 \\
IPB C10 x IPB C15 & 9.42 & 7.39 & 10.69 & 7.38 \\
\hline \multicolumn{7}{c}{ Kadar Air } & \multicolumn{4}{c}{ Daya Hantar Listrik } \\
\hline IPB C2 x IPB C9 & -49.79 & -111.19 & -11.29 & -11.81 \\
IPB C2 x IPB C10 & -7.32 & -201.39 & -10.67 & -14.09 \\
IPB C2 x IPB C15 & 55.94 & -188.80 & -3.26 & -7.44 \\
IPB C9 x IPB C10 & -44.53 & -42.75 & -9.49 & -13.43 \\
IPB C9 x IPB CI5 & -80.75 & -36.74 & -2.43 & -7.17 \\
IPB C10 x IPB C15 & 6.07 & 3.87 & -14.44 & -14.91 \\
\hline
\end{tabular}

Nilai duga heritabilitas dalam arti sempit $\left(h^{2} n s\right)$ tertinggi adalah laju penurunan vigor pada panjang radikula (0.47) disusul oleh laju penurunan vigor daya berkecambah dan panjang hipokotil (0.80 dan 0.34), dan heritabilitas dalam arti sempit 0 pada laju penurunan vigor (kecepatan tumbuh dan daya hantar listrik), hal ini menunjukkan bahwa ragam dominan nilainya sangat tinggi.

Hibrida yang baik dihasilkan dari persilangan yang memiliki daya gabung umum dan heterosis yang tinggi. Nilai heterosis untuk IPB C2 x IPB C15 bernilai positif untuk hampir semua tolok ukur (Tabel 7) yaitu PR (4.11), PH (15.27), DB (8.8), Kct (63.63), KA (55.94) dan DHL (-7.44). Berdasarkan syarat tersebut di atas, tetua yang baik untuk pembentukan hibrida cabai vigor benih tinggi adalah IPB C2 dengan IPB CI5.

\section{KESIMPULAN}

Analisis pendugaan parameter genetik vigor benih cabai menunjukkan bahwa vigor penyimpanan benih cabai dipengaruhi oleh faktor genetik. Genotipe cabai IPB C15 mempunyai nilai daya gabung umum yang tinggi untuk vigor penyimpanan benih sehingga dapat dijadikan sebagai tetua untuk perakitan varietas $F 1$ hibrida dengan vigor daya simpan tinggi. Kombinasi persilangan tetua IPB C2 x IPB C15 menghasilkan benih yang memiliki vigor penyimpanan tinggi.

\section{DAFTAR PUSTAKA}

Akram, M., U.A. Saif, M. Munir. 2007. Inheritance of trait related to seedling vigor and grain yield in rice (Oryza sativa L.). J. Bot. 39(1): 37-45.

Baihaki, A. 2009. Manfaat dan implementasi UU No. 29 TH 2000 tentang PVT dalam pembangunan industri perbenihan. Komisi Nasional Sumber Daya Genetik.

Basuki, N. 1986. Pendugaan parameter genetik dan hubungan antara hasil dengan beberapa sifat agronomi serta analisis persilangan dialel pada ubi jalar (Ipoemoea batatas (L.) Lamb.) Disertasi. Sekolah Pascasarjana, Institut Pertanian Bogor. Bogor. 
Clerkx, E.J., M.E. El-Lithy, E. Vierling, G.J. Ruys, D.H.S. Blankestijn, P.C. Groot, D. Vreugdenhi, M. Koornneef. 2004. Analysis of natural allelic variation of Arabidopsis seed germination and seed longevity traits between the accessions Landsberg erecta and Shakdara using a new recombinant inbreed line population. Plant Physiol. 135: 432-443.

Desita, A.Y., D. Sukma, M. Syukur. 2015. Evaluasi karakter hortikultura galur cabai hias IPB di kebun percobaan Leuwikopo. J. Hort. Indonesia. 6(2): 116-123.

Mahmud, M., Y. Suryadi, M.A. Suhendar. 1999. Pengendalian Penyakit Layu Bakteri (Pseudomonas solanacearum) dengan Bioteknologi Pertanian. Laporan Hasil Penelitian. Balai Penelitian Bioteknologi Tanaman Pangan Bogor. Bogor.

Roy, D. 2000. Plant Breeding Analysis and Exploitation of Variation. Narosa Publ House. New Delhi.

Sadjad, S, E. Murniati. S. Ilyas. 1999. Parameter Pengujian Vigor Benih. PT. Grassindo bekerjasama dengan Perum Sang Hyang Seri. 185 hal. Jakarta.

Singh, R.K., B.D. Chaudary. 1979. Biometrical: Methods in Quantitative Genetic Analysis. Kalyani Publishers.
Sujiprihati, S. 1996. Heterosis, combining ability and yield production in hybrids from local maize inbreed lines. Disertasi. Faculty of Agriculture, Universiti Pertanian Malaysia. Malaysia.

Sujiprihati, S, M. Syukur, R. Yunanti. 2005. Pendugaan parameter genetik dan heritabilitas beberapa karakter vegetatif dan hasil jagung manis. Agrotropika. 10(2): 75-78.

Susanto, U., A. Baihaki, R. Setiamiharja, T.A.D. Haryanto. 2001. Variabilitas genetik dan daya gabung umum galurgalur jagung melalui analisis top cross. Zuriat. 12(1): 1-6.

Syukur, M., S. Sujiprihati, R. Yunianti, K. Nida. 2010. Pendugaan komponen ragam, heritabilitas dan korelasi untuk menentukan kriteria seleksi Cabai (Capsicum annuum L.) populasi F5. J. Hort. Indonesia. 1(2): 74-80.

Tchiagam, J.B.N., M.B. Joseph, D.F. Ngakeu, Y.N. Nicolas, Y. Emmanuel. 2011. Diallel analysis of cowpea (Vigna unguilata (L.) Walp.) for some physical properties of seed under the Sudanoguinean conditions. Agric and Bio. J. North America. 2(4): 2151-7517. 